\title{
Ultrastructure and X-ray Microanalysis of the Antibacterial Effects of Stem Bark Ethanol Extract of Acacia mearnsii De Wild Against Some Selected Bacteria
}

\author{
Olufunmiso O. Olajuyigbe*, Aderonke A. Olajuyigbe and Anthony J. Afolayan
}

Medicinal Plant and Economic Development (MPED) Research Centre, Department of Botany, University of Fort Hare, Alice 5700, South Africa.

\begin{abstract}
To investigate the ultrastructural changes, X-ray microanalysis and leakages of protein and lipids from bacteria treated with the ethanolic extract of Acacia mearnsii. The ultrastructural changes were investigated using scanning electron microscope (SEM). The X-ray microanalyses were determined using electron dispersive spectroscopy (EDS) while the protein and lipid leakages were determined spectrophotometrically. The scanning electron microscopy indicated varied ultrastructural changes in the morphology of bacterial cells treated with the ethanol extract. The X-ray microanalysis showed significant differences between the elemental contents of extract-treated and broth-cultured and untreated bacteria strains. Lipids and proteins were leaked to a greater extent from the extract-treated bacterial strains in comparison with the broth-cultured and untreated ones used as controls. The possible antibacterial effects of the ethanol extract of $A$. mearnsii could be inhibition of a significant step in peptidoglycan assembly, inhibition of metabolic processes as well as the cell wall and cell membrane disruptions resulting in the efflux of lipid and protein in all the bacteria tested. This is a report identifying elemental components and associating their disintegrations in bacterial isolates with the antibacterial activities of medicinal plants. While ethanol extract of $A$. mearnsii caused ultrastructural changes, breakdown of elemental components into different elements and leaked lipid and protein from treated bacteria, the physiological damages to the cell wall further justify the bactericidal ability of the extract.
\end{abstract}

Keywords: Ultrastructural changes, microanalysis, elemental contents, physiological damages.

*Correspondence: funmijuyigbe12@yahoo.com; +2348101994655

(Received: 26 July 2018; accepted: 04 October 2018)

Citation: Olufunmiso O. Olajuyigbe, Aderonke A. Olajuyigbe and Anthony J. Afolayan, Ultrastructure and X-ray Microanalysis of the Antibacterial Effects of Stem Bark Ethanol Extract of Acacia mearnsii De Wild Against Some Selected Bacteria, J Pure Appl Microbiol., 2018; 12(4):2217-2228. http://dx.doi.org/10.22207/JPAM.12.4.61

(c) The Author(s) 2018. Open Access. This article is distributed under the terms of the Creative Commons Attribution 4.0 International License which permits unrestricted use, sharing, distribution, and reproduction in any medium, provided you give appropriate credit to the original author(s) and the source, provide a link to the Creative Commons license, and indicate if changes were made. 


\section{INTRODUCTION}

Medicinal plants are of significant importance because of their roles in the treatment of microbial infections. They have provided a good source of anti-infective agents and many of them remain highly effective in the fight against microbial infections. They are the richest bioresource of drugs for folkloric medicine, modern medicines, pharmaceutical intermediates and chemical entities for synthetic drugs [1]. Their antibacterial activities as indicated by their minimum inhibitory concentration $\left(\mathrm{MIC}_{\text {index }}\right)$ index against any given pathogen are important in defining the nature of their antibacterial effects. The antibacterial effects, however, depend on the nature and types of phytochemicals present in the plant materials, extract preparation, solvent used and the susceptibility of test bacteria [2] while the variation in different bacterial susceptibility depended on the presence of intrinsic levels of tolerance to antimicrobials in the tested microorganisms [3] and the structural physiology of the bacterial cell wall.

Pharmacologically, phytochemicals exhibit a wide range of biological effects and contribute to the anti-inflammatory, anti-bacterial and anti-fungal properties of plants [4]. They have protective or disease preventive activities [5], modulate ion channel activity of bacterial cell membrane by increasing permeability [6] and may acts as permeability enhancers that decreases or removes extracellular layer resistance reversibly and allow anti-infective agents to pass through bacteria membrane [7]. Its interaction with bacterial cytoplasmic membrane might lead to disruption of membrane structure resulting in dissipation of the transmembrane potential and eventual cell death by forming channels or pores that are proposed to lead to the leakage of cell contents and cell death [8]. While some phytochemicals bind physiologically to cell walls interfering with the ability of pathogens to bind to cell receptors 9,10 ] and some of them are particularly targeting drug-resistant bacterial strains $[11,12]$, some plant natural products are reported to modulate or modify bacterial resistance [13-15].

Acacia mearnsii De Wild. (Fabaceae) is a member of the genus Acacia. It is considered a wild and a notorious plant because of its ability to compete with indigenous plants and populate a large expanse of land sporadically. It was introduced into South Africa over 150 years ago basically for its high tannin contents [16] and Olajuyigbe and Afolayan [17-19] reported that $A$. mearnsii is a medicinal plant of ethnobotanical and pharmacological importance. Sequel to these earlier reports indicating significant antibacterial activities, investigating the potential effects of the crude extract of $A$. mearnsii becomes imperative to establish the possible means through which it produces an effect on different bacterial strains. Hence, this study was designed to determine the ultrastructural changes, $\mathrm{X}$-ray microanalysis and leakages from some selected bacteria as the possible means through which the ethanolic extract of this plant exert its antibacterial effects.

\section{MATERIALS AND METHODS}

\section{The bacteria used for the study}

The bacteria used in this study included Escherichia coli ATCC 8739, Shigella flexneri KZN, Proteus vulgaris ATCC 6830, Staphylococcus aureus ATCC 6538 and Bacillus pumilus ATCC 14884. These organisms were obtained from the Department of Biochemistry and Microbiology, University of Fort Hare, Alice, South Africa.

\section{Collection and preparation of plant material}

The bark materials of the Acacia mearnsii De Wild were collected from the plant growing within the University of Fort Hare campus in Alice, South Africa. The plant was authenticated by Prof. D.S. Grierson in the Department of Botany and a voucher specimen (OLAJ Med 2010/01) was prepared and deposited in the Griffen Herbarium of the University. The bark sample was air-dried at room temperature and pulverized using a milling machine. To prepare the bark extract, about 100 $\mathrm{g}$ of the pulverized sample was extracted with $500 \mathrm{ml}$ of ethanol for $48 \mathrm{~h}$ with shaking (Stuart Scientific Orbital Shaker, UK). The extract was filtered through Whatman No. 1 filter paper and concentrated under reduced pressure at $40^{\circ} \mathrm{C}$ using a rotary evaporator (Laborota $4000-$ efficient, Heldolph, Germany). The crude extract collected was allowed to dry at room temperature to a constant weight. The extract was redissolved in ethanol before being diluted with sterile distilled water to the required concentrations for bioassay analysis. The extract solution for bioassay 
analysis was sterilized by filtering through 0.45 ìm membrane filter and tested for sterility by introducing $2 \mathrm{~mL}$ of the extract into $10 \mathrm{~mL}$ of sterile nutrient broth before being incubated at $37^{\circ} \mathrm{C}$ for $24 \mathrm{~h}$. Absence of turbidity in the broth after the incubation period showed that the extract was sterile.

\section{Determination of the effect of ethanolic extract on cell morphology}

The minimum inhibitory concentrations of the extract were determined by the macrobroth dilution methods [20]. The inoculum of each test strain was standardized at $5 \times 10^{6} \mathrm{CFU} / \mathrm{mL}$ using McFarland Nephelometer standard. The ethanol extract was serially diluted with Mueller Hinton broth to give final concentrations of $0.0195 \mathrm{mg} /$ $\mathrm{ml}$ to $10 \mathrm{mg} / \mathrm{ml}$. The tubes were inoculated with 100 iL of each bacterial suspension. The tubes were incubated at $37^{\circ} \mathrm{C}$ for $24 \mathrm{~h}$. The MIC was the lowest concentration of the extract that yielded no visible growth after the incubation[21].

For the determination of the effects of the extract on cell morphology, one milliliter of each of the adjusted bacterial culture was added to $9 \mathrm{~mL}$ of the plant extract at $4 \times \mathrm{XIC}$ and kept at laboratory temperature $\left(28^{\circ} \mathrm{C}\right)$ for $2 \mathrm{~h}$. Bacterial isolates cultured in broth without the extract, considered as untreated bacteria and used as controls, were prepared in Mueller Hinton broth medium and incubated for the same period of time. The bacterial cells were harvested by centrifuging at $10000 \mathrm{rpm}$ for $10 \mathrm{~min}$ and subsequently washed three times with phosphate buffer ( $\mathrm{pH}$ 7.2). The bacterial pellets were resuspended in $2.5 \%$ glutaraldehyde and kept for 2 $\mathrm{h}$ to fix the bacterial cell. The fixed bacterial cell suspensions were centrifuged at $10000 \mathrm{rpm}$ for $10 \mathrm{~min}$, washed and re-suspended in buffer $\mathrm{pH}$ 7.2) from where the cells were then deposited on a $0.45-\mu \mathrm{m}$-pore-size membrane filter (Schleicher \& Schuell, Dassel, Germany). The bacterial cells on the membrane filters were dehydrated with a graded series of acetone/water washes $(20 \%$, $50 \%, 70 \%, 90 \%$ and $100 \%$ acetone) to gradually remove water from the cells without physical damage. The dehydrated bacterial cells were mounted on a stub and allowed to dry before being sputtered with a small amount of gold/palladium (lone coater: EIKO IB.3) to avoid charging in the microscope. Microscopy was performed with a
JEOL JSM-6390LV Scanning Electron Microscope (Japan). Five different secondary electron images were taken with an accelerating voltage of $15 \mathrm{kV}$ to assess the ultrastructural changes in each of the bacterial strains.

\section{Energy Dispersive spectroscopy (EDS) of the bacterial cells}

To determine the influence of the extract on the elemental components of the bacteria cells, a beam of electrons was focused on extract-treated and broth-cultured, harvested and untreated bacterial cells to scan the cells at three different field of view or points where examination of its elemental composition was desired. The detection and determination of elements with the EDS was based on the emission of characteristic $X$-rays by the bacteria cells under bombardment with electrons using JEOL JSM-6390LV Scanning Electron Microscope equipped with Electron Dispersive Spectroscope. The dispersed spectra produced a pattern of $\mathrm{X}$-rays characteristic of the element excited. Only the most intense emissions, the so-called K2 and Ká lines, were analyzed with the spectrometers [22].

Determination of Lipid leakage from bacteria cells Phospho-vanillin was prepared as previously described by Frings and Dunn [23]. Vanillin (0.6 g) (Sigma Chemical Co., St. Louis, Mo. 63118) was dissolved in $10 \mathrm{ml}$ of absolute ethanol before diluting to $100 \mathrm{~mL}$ with distilled water. This solution was mixed with $400 \mathrm{~mL}$ of concentrated phosphoric acid with constant stirring before being stored at room temperature in a brown bottle. The lipid leakage assay was carried out as described by Van Handel and Day ${ }^{24}$ and Kaufmann and Brown [25]. Briefly, bacterial cells were harvested from an overnight broth culture by centrifuging at $10000 \mathrm{rpm}$ for $10 \mathrm{~min}$. The harvested cells were used to prepare $10^{6} \mathrm{CFU} / \mathrm{mL}$. The standardized cell suspension was treated with MIC and 2 X MIC of the extract and the samples were incubated at $37^{\circ} \mathrm{C}$ for $120 \mathrm{~min}$. After incubating at $37^{\circ} \mathrm{C}$ for $30 \mathrm{~min}$, each cell suspension was sampled at 30 min interval and centrifuged at $10000 \mathrm{rpm}$ for $10 \mathrm{~min}$. Sulfuric acid $(0.2 \mathrm{~mL})$ was added to a replicated small portion of the supernatant (10 $\mu \mathrm{L}$ ) in tubes and heated in water bath for $10 \mathrm{~min}$ at $100^{\circ} \mathrm{C}$. Vanillin-phosphoric acid reagent was added to the mixture before being removed from water bath, vortexed and allowed to cool while 
the optical density was measured at $525 \mathrm{~nm}$. The concentration of lipid leakage was estimated from linoleic acid standard curve used as standard.

\section{Determination of Protein leakage from bacteria} cells

To determine the leakage of intracellular materials from the cells, the bacteria cells were treated with the $1 \times \mathrm{MIC}$ and $2 \times \mathrm{MIC}$ of the extract and the samples were incubated at $37^{\circ} \mathrm{C}$ for 120 min. Immediately the bacteria was introduced into the extract solutions and at an interval of 1 $\mathrm{h}$ incubation period, $1 \mathrm{~mL}$ of the bacteria-extract mixture was centrifuged at $10000 \mathrm{rpm}$ for 10 min. Ten microlitre $(10 \mu \mathrm{L})$ of the supernatant was dispensed into 96 - well microtitre plate and $250 \mu \mathrm{L}$ of Bradford's reagent was added. The mixtures were incubated at room temperature for 15 min with intermittent shaking. The amount of protein released from the cells was determined spectrophotometrically at $525 \mathrm{~nm}$ by the method of Bradford [26]. The concentrations of protein leaked were extrapolated from Bovine Serum Albumin (BSA) which was used as a standard.

\section{Statistical analysis}

Data were expressed as means \pm standard deviations (SD) of three replicate determinations and then analyzed by SPSS V.16 (Statistical Program for Social Sciences, SPSS Corporation, Chicago, IL). One way analysis of variance (ANOVA) and the Duncan's New Multiple-range test were used to determine the differences among the means. $p$ values $<0.05$ were regarded to be significant.

\section{RESULTS}

The minimum inhibitory concentrations (MIC) of the extract against bacterial isolates ranged between $0.078 \mathrm{mg} / \mathrm{ml}$ and $0.313 \mathrm{mg} / \mathrm{ml}$ as shown in Table 1. Also, the ethanol extract of $A$. mearnsii had varied effects on the ultrastructures of the individual cells. In Figures 1 - 5, all the broth-cultured, harvested and untreated bacterial strains had their morphological features intact. Escherichia coli had short rods, smooth surface and round ends with no cellular materials attached to their surfaces. Shigella flexneri had regular rod-shaped cells. Proteus vulgaris remained intact within matrices. Bacillus pumilus cells appeared as intact, smooth and shorts rods while Staphylococcus aureus cells were intact and were typically spherical in shape. On treating them with the extract, there were significant changes in their morphology. In $E$. coli treated with the extract (Fig. 1B), no cellular materials were found on the surfaces of most of the cell. Many cells were totally collapsed with depressions in the middle. Few dead cells were elongated with rough surfaces while some were bulged. In Figure $2 \mathrm{~B}$, treating $S$. flexneri with the extract resulted in changing the rod-shaped cells to polygon-shaped, collapsed or squeezed cells that looked coccoid in feature suggesting inflammation and bursting of cells. When $P$. vulgaris was treated with the extract (Fig. 3B), the cells were totally damaged. High percentage of the cells collapsed and many cells were shred into pieces. The cell collapsing was observed at both end of each bacterial cell while most treated cells appear longer than the control cells. Treating $B$. pumilus with the extract caused a massive death of cells (Fig. 4B). In affected but not shredded cells, there were collapsed twisting cells while few cells were swollen. In Fig. 5B,

Table 1. Minimum inhibitory concentrations of Acacia mearnsii against bacterial isolates

\begin{tabular}{lc}
\hline Bacterial isolates & MIC (mg/ml) \\
\hline Escherichia coli ATCC 8739 & 0.156 \\
Shigella flexneri KZN & 0.078 \\
Proteus vulgaris ATCC 6830 & 0.156 \\
Staphylococcus aureus ATCC 6538 & 0.313 \\
Bacillus pumilus ATCC 1484 & 0.156 \\
\hline
\end{tabular}

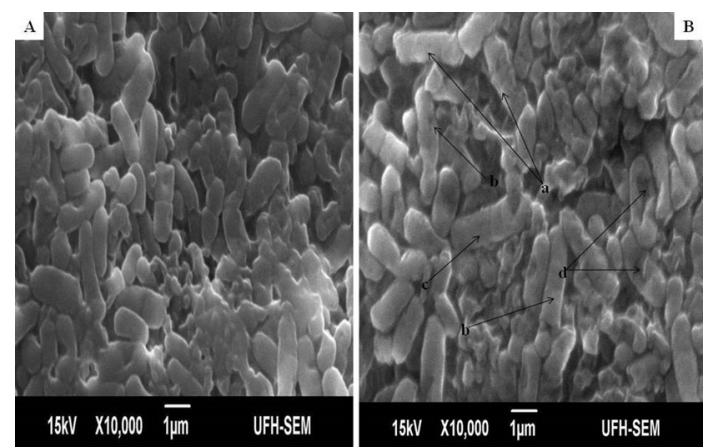

Fig. 1. Influence of ethanol extract on the morphology of E. coli. $\mathrm{A}=$ Extract untreated $E$. coli; $\mathrm{B}=$ Extract treated E. coli. $(a=$ dead cells with rough surfaces; $b=$ collapsed and elongated dead cells; $c=$ bulged or swollen dead cells; $d$ = depressions in dead cells). 
many $S$. aureus cells treated with the extract were destroyed. While many cells appeared unaffected, some cells appeared swollen or bigger in size than the control cells. The surfaces of the unaffected but inflamed cells were smooth and no pores were observed.

In determining the differences between the elemental components of these bacterial isolates, the presence of Carbon (C), Nitrogen $(\mathrm{N})$, Oxygen (O), Sodium ( $\mathrm{Na})$, Magnesium $(\mathrm{Mg})$, Aluminum (Al), Chlorine (Cl), Silicon (Si), Phosphorus (P), Sulphur (S), Potassium (K), Calcium (Ca) and Copper ( $\mathrm{Cu}$ ) were investigated. The micrographs of the electron dispersive $\mathrm{X}$-ray spectroscopy of these bacterial strains revealed their elemental components as shown in Figure $6-10$. The average weights (\%) of the elemental components of the extract-treated group and the control bacteria strains were presented in Table 1 . The results showed that there were significant differences in the weight (\%) of the element observed in the extract-treated group in comparison to those of the controls. From the micrographs, the peaks of the elements present in the extract-untreated bacterial strain were higher than those obtained from the treated group. These differences were, however, shown in Table 1. In comparison to the untreated B. pumilus, extracttreated $B$. pumilus had increases in the weight (\%) of $\mathrm{C}, \mathrm{N}, \mathrm{O}, \mathrm{Na}, \mathrm{Al}, \mathrm{Mg}$ and $\mathrm{Cl}$ and reductions in the weight (\%) of $\mathrm{Si}, \mathrm{P}, \mathrm{S}, \mathrm{K}, \mathrm{Ca}$ and $\mathrm{Cu}$. The increases in the $\mathrm{C}, \mathrm{N}$ and $\mathrm{O}$, which are major elements essential to life, suggested rapid metabolic and growth processes in B. pumilus, possibly, in response to the environmental perturbation due to the presence of the extract. With the exception of $P$. vulgaris, this observation may be appropriated to other bacterial strains treated with this extract since one of the major elements essential to life was higher in the treated bacteria than the untreated specimens. In comparison to the untreated bacterial cells, $\mathrm{Na}$ and $\mathrm{Cl}$ were found to increase in weight (\%) in all the test isolates. While $\mathrm{N}, \mathrm{Na}, \mathrm{Mg}, \mathrm{Al}, \mathrm{Si}, \mathrm{Cl}, \mathrm{K}$ and $\mathrm{Cu}$ were found to increase in weight (\%) in extract-treated $E$. coli, $\mathrm{Na}, \mathrm{Al}, \mathrm{S}, \mathrm{Cl}$ and $\mathrm{K}$ were found to increase in weight (\%) in S. flexneri and $\mathrm{N}, \mathrm{Na}, \mathrm{Mg}, \mathrm{Cl}, \mathrm{K}, \mathrm{Ca}$ and $\mathrm{Cu}$ had increased in weight (\%) in $P$. vulgaris.

Considering the carbon contents of these cells, the results showed that the carbon

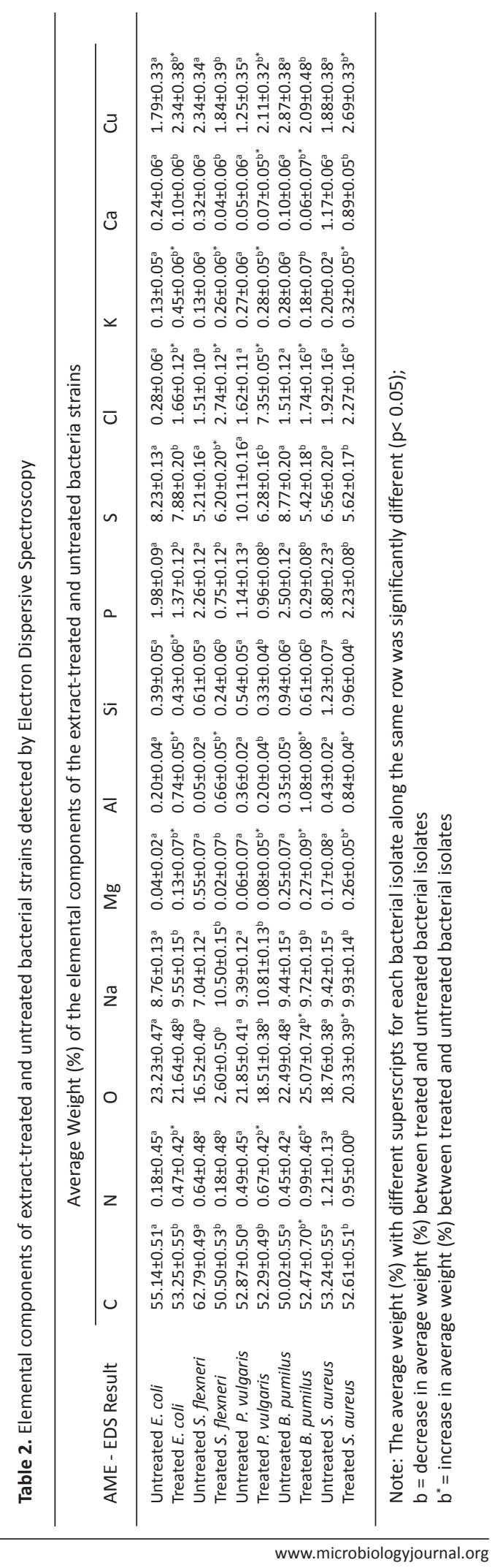




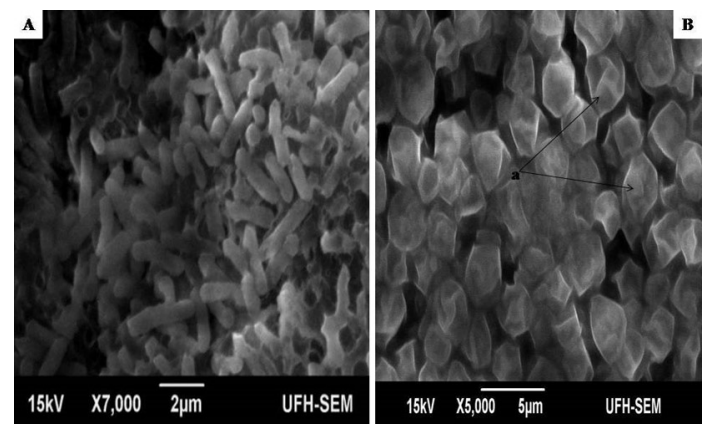

Fig. 2. Influence of ethanol extract on the morphology of S. flexneri. $\mathrm{A}=$ Extract untreated $\mathrm{S}$. flexneri; $\mathrm{B}=$ Extract treated S. flexneri. (a = polygon shaped, collapsed or squeezed cells).
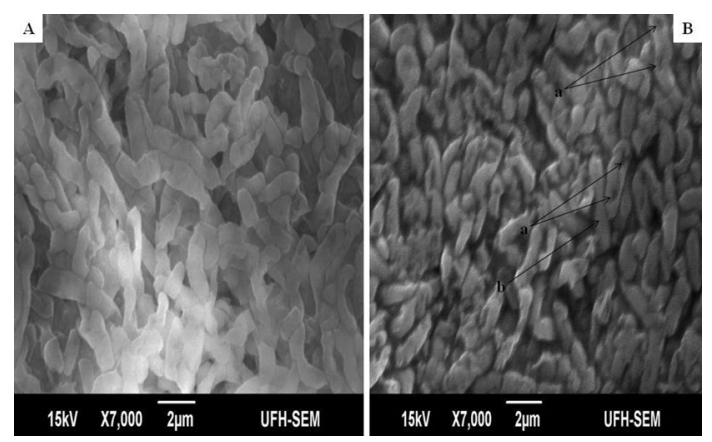

Fig. 3. Influence of ethanol extract on the morphology of $P$. vulgaris. $\mathrm{A}=$ Extract untreated $P$. vulgaris; $\mathrm{B}=$ Extract treated $P$. vulgaris. $(\mathrm{a}=$ dead cell with depression at the polar ends; $b=$ elongated cell)
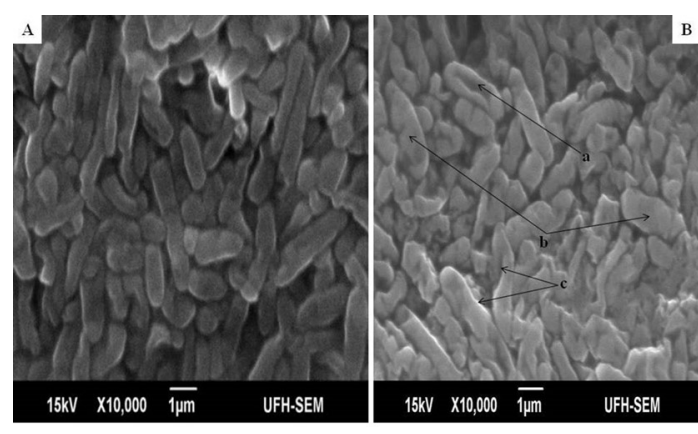

Fig. 4. Influence of ethanol extract on the morphology of B. pumilus. $A=$ Extract untreated $B$. pumilus; $B=$ Extract treated $B$. pumilus. $(a=$ depressed or collapsed cell; $b=$ swollen cells; $c=$ collapsed cells with twisting).
(C) content of S. flexneri was the highest for the control group while carbon (C) in E. coli was the highest for the extract-treated strains. For the nitrogen content, there was an increase in the nitrogen content of treated $E$. coli, P. vulgaris and B. pumilus while there was a loss in those of $S$. flexneri and S. aureus. Considering other elements in these bacterial strains, $\mathrm{Mg}, \mathrm{Al}$ and $\mathrm{K}$ were found to increase in all the bacteria except in S. flexneri, $P$. vulgaris and $B$. pumilus respectively. Except in $P$. vulgaris, the weight of $\mathrm{Ca}$ was decreased in all the extract treated bacteria while that of $\mathrm{Cu}$ was decreased in S. flexneri and B. pumilus. It may, therefore, be appropriate to infer from the differences between the elemental components of the two groups of bacteria that the increments was due to the rapid replication, synthesis of micromolecules and rapid growth of these isolates in order to survive in the challenged environment. However, the varied reduction in the elemental components of the treated isolates, compared to those used as control, could be attributed to the ability of the extract to breakdown the synthesized micromolecules and attack the basic mechanisms underlining replication, growth and development in bacteria.

The determination of the lipid and protein leakage ability of this extract showed its ability to cause leakages was time and concentration dependent (Figures 11 and 12). The lipid and protein leakages that resulted from 2 X MIC were higher than those obtained from 1 X MIC of the extract. In these assays, leaked lipid and protein
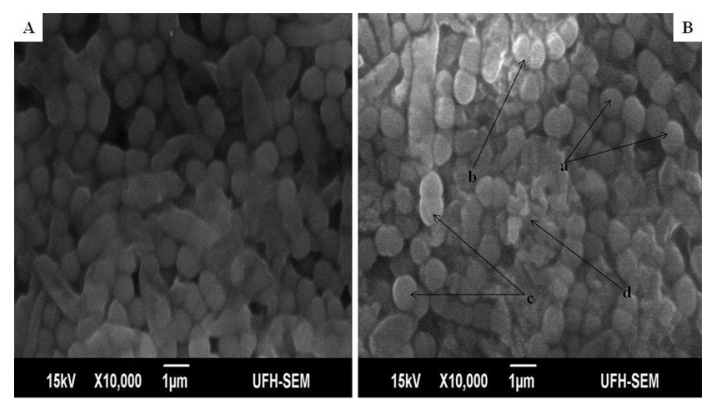

Fig. 5. Influence of ethanol extract on the morphology of $S$. aureus. A = Extract untreated S. aureus; B = Extract treated $S$. aureus. $(a=$ intact but affected cells; $b=$ dead cells with destroyed cells; $c=$ swollen cells; $d=$ shredded cells) 

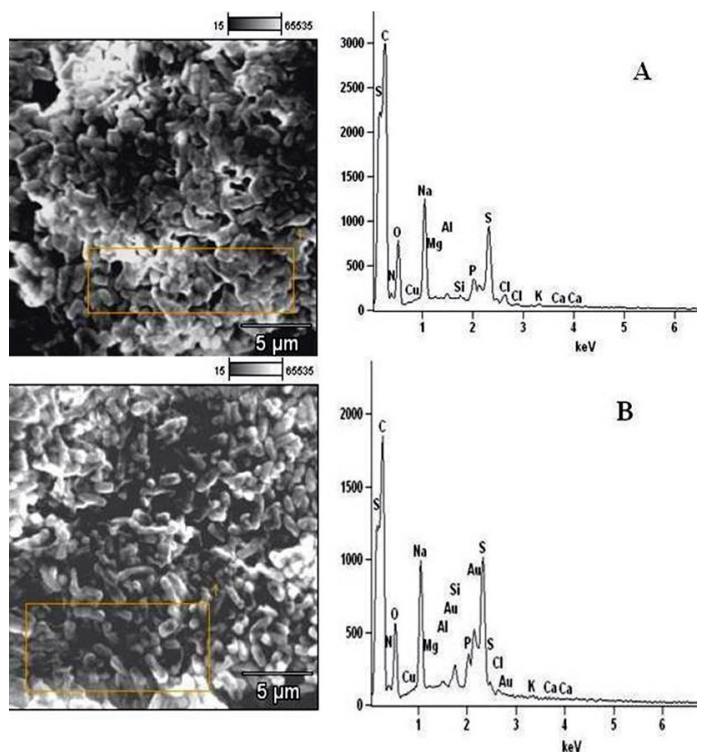

Fig. 6. Elemental components of $(A)$ extract-untreated E. coli and (B) extract-treated E. coli.
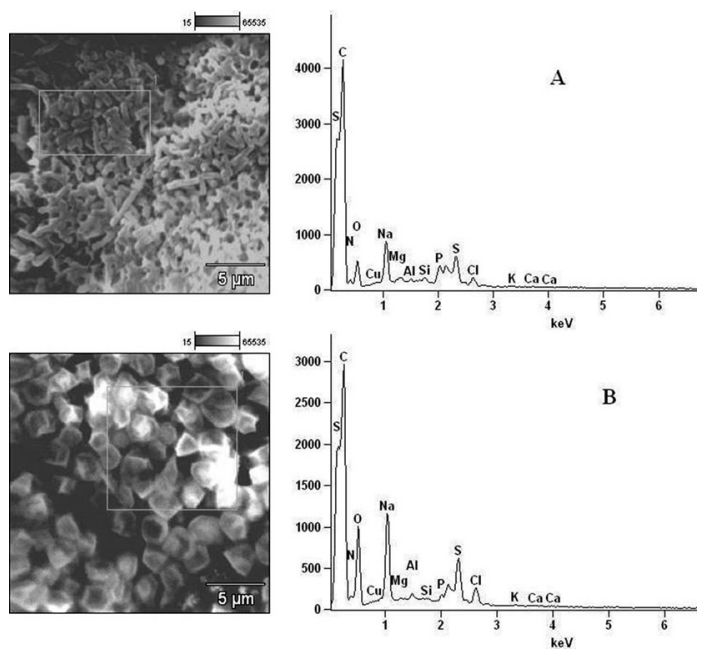

Fig. 7. Elemental components of (A) extract-untreated S. flexneri and (B) extract-treated S. flexneri.

in S. aureus were the highest compared to those of the other test isolates. While the protein leaked was very high in S. flexneri, this organism had the least lipid leaked from its treatment with the different concentrations of the extract in comparison with those obtained from the other strains. On the other hand, protein leaked from $S$. aureus at MIC and 2 X MIC were generally higher than those obtained from other bacterial strains.
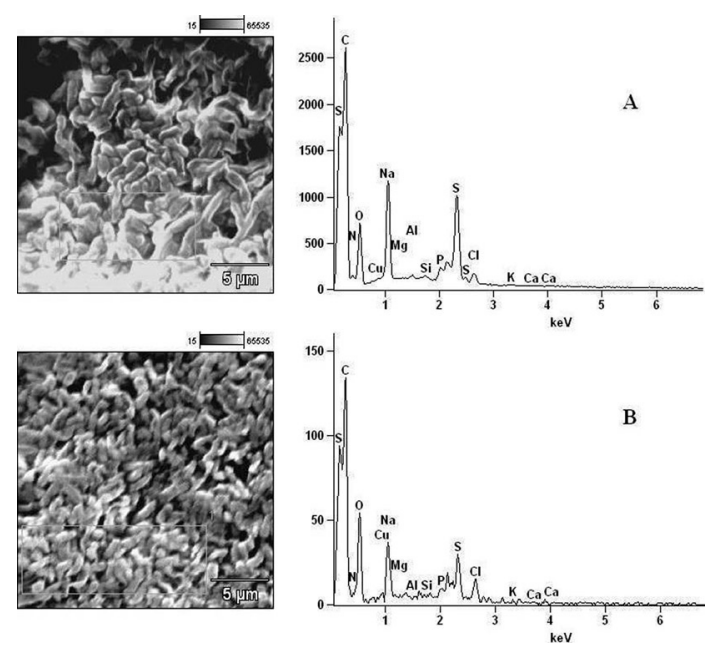

Fig. 8. Elemental components of (A) extract-untreated P. vulgaris and (B) extract-treated $P$. vulgaris.
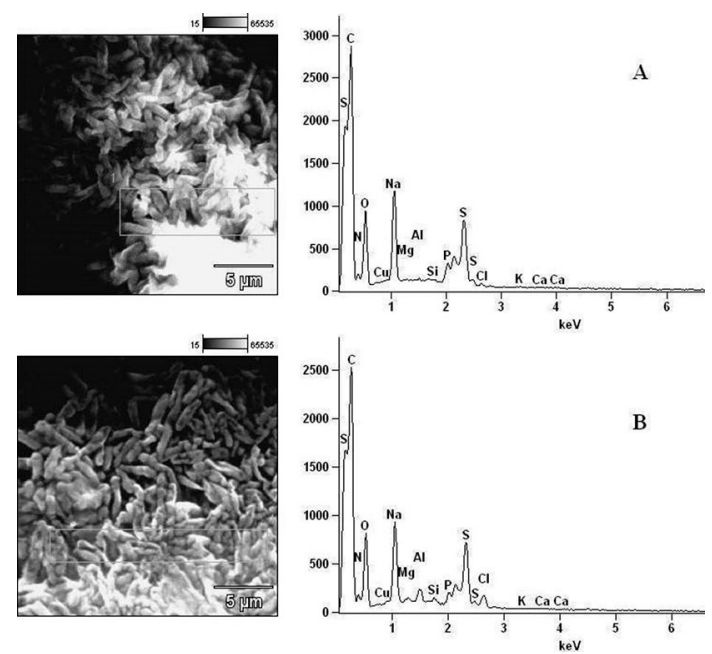

Fig. 9. Elemental components of (A) extract-untreated B. pumilus and (B) extract-treated B. pumilus.

The amounts of the lipid leaked from the bacteria treated with the MIC ranged from 68 to $325 \mu \mathrm{g} / \mathrm{mL}$ while those of the 2 X MIC ranged between 83.07 and $385.97 \mu \mathrm{g} / \mathrm{mL}$. While the protein leaked at the MIC ranged between 333.3 and $427.3 \mu \mathrm{g} / \mathrm{mL}$, those obtained at the $2 \mathrm{X}$ MIC ranged between 354.0 and $542.7 \mu \mathrm{g} / \mathrm{mL}$. The results showed that there are differences between the concentrations of the lipids and proteins leaked. 

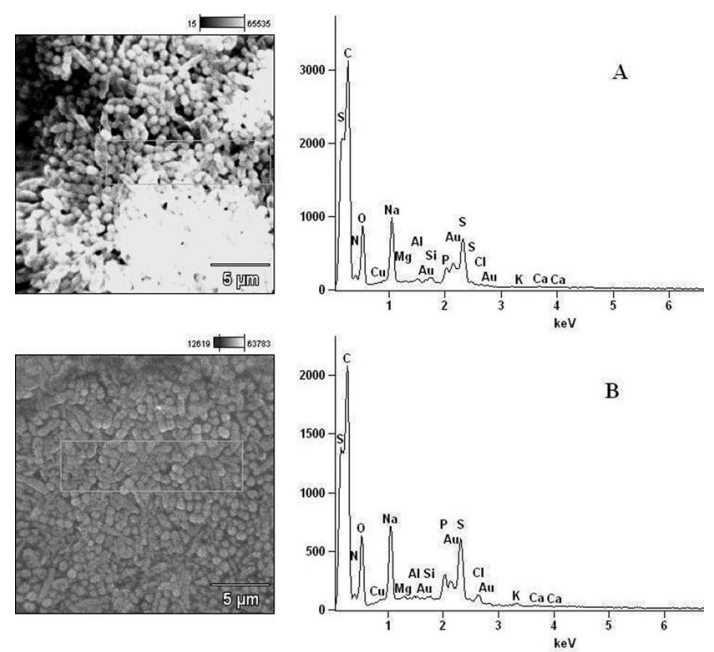

Fig. 10. Elemental components of (A) extract-untreated S. aureus and (B) extract-treated S. aureus.
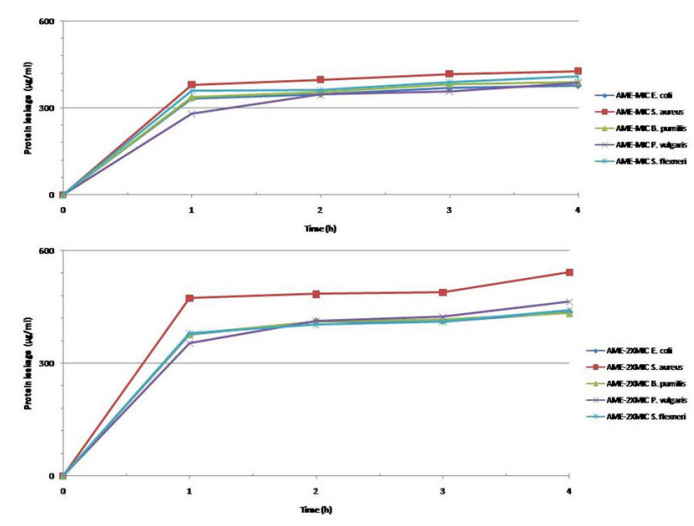

Fig. 11. Leakage of protein from different bacteria after treatment at their MIC and 2xMIC.

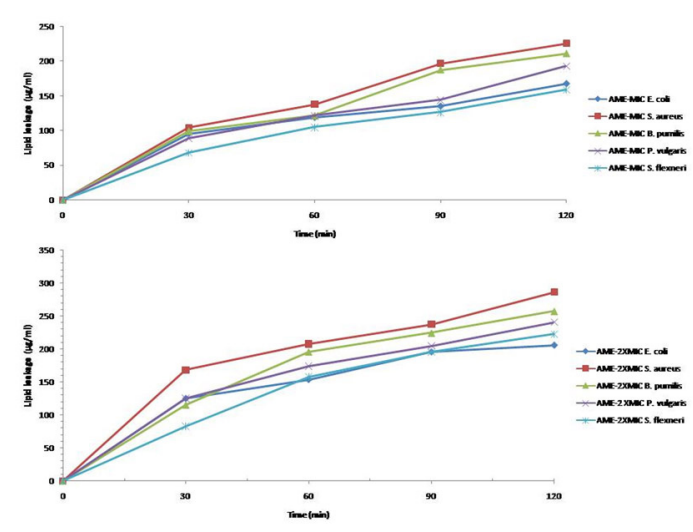

Fig. 12. Leakage of lipid from different bacteria after treatment at their MIC and $2 \times$ MIC.

\section{DISCUSSION}

Many studies have investigated the effect of crude extracts on different bacterial strains to determine one of the possible mechanisms through which they exert their antibacterial activities in vitro $[27,28]$. In this study, the scanning electron microscopy (SEM) demonstrated clearly that the ethanol extract of $A$. mearnsii caused significant ultrastructural changes or damages in the tested bacteria. The morphological changes of varied degrees including bulging, swelling and elongation of intact cells signified the inflow of solutes containing phytochemicals into the cells followed by bursting as shown by the shredded bacterial cells. The shrinking, collapse and depression in the cells could be attributed to ex-osmosis of cytoplasmic contents that resulted in plasmolysis of bacterial cells or imperfect synthesis of the cell wall after treatment. Of significance is the ability of the extract to change the morphology of $S$. flexneri from rods to polygon shaped cells while most $S$. aureus cells appeared unaffected. In S. aureus, thickening of the cell wall was a form of defense against antibiotics and compounds that inhibit the cell wall synthesis $[29,30]$. The thickened cell walls became more rigid and the thickening affected the membrane permeability so that the cells became more easily broken. Katzung [31] indicated that the cell membranes were also damaged through this process. The morphological changes observed in these bacterial strains could imply that the extract inhibited cell wall synthesis, caused membrane damage and possessed different antibacterial components exerting different mechanisms of action at different target sites.

With respect to the rod-shaped $S$. flexneri changed to squeezed, collapsed, polygon-shaped cocci and varied elongations observed in other bacterial strains, the inhibition of a significant step in peptidoglycan assembly could be connoted as a possible effect of the extract. Schwarz et al. [32] reported that lateral wall elongation and septum formation were biochemical processes involved during the growth of rod-shaped bacterial cells. Higgins and Shockman [33] showed that cocci expansion occurred through cross wall formation and that the presence of additional genetic information was required for the lateral wall formation. Satta et al. $[34,35]$ suggested that shape determination and maintenance of bacterial rods 
depend on the activity of the two biochemical reactions. While Satta et al. [36] showed that the actual shape of rod-shaped bacteria was determined by the balance between these two competing biochemical reactions occurring in the terminal stages of peptidoglycan synthesis, Canepari et al. [37] and Satta et al. [35,38] reported that correct balance between the two biochemical reactions would result in normal shaped rods. They indicated that prevalence of the reactions for lateral wall elongation would result in long rods while the prevalence of the reactions for septum formation would lead to formation of cocci or coccobacilli. In view of these earlier reports, the distorted shapes of S. flexneri as well as the constriction and the elongations of some cells in other bacterial strains, used in this study, could be attributed to the ability of the ethanol extract to inhibit the reactions leading to septum formation to produce elongated rods in S. flexneri and inhibition of reactions leading to lateral wall elongation in other isolates to produce cocci.

In nature, there is a great breadth of microbial metabolism. Cultivated bacteria convert the chemical energy of a growth substrate to work and biosynthetic processes underlining both survival and replication. Consequently, major elements such as $\mathrm{H}, \mathrm{C}, \mathrm{O}, \mathrm{N}, \mathrm{P}, \mathrm{S}, \mathrm{Cl}, \mathrm{K}, \mathrm{Na}, \mathrm{Ca}, \mathrm{Mg}$, $\mathrm{Se}, \mathrm{Zn}, \mathrm{Fe}, \mathrm{Mn}, \mathrm{Cu}, \mathrm{Co}, \mathrm{Ni}$ and Mo synthesized during growth have been identified in bacterial cells [39-41]. These elements have been related to the microorganisms' genes that enable them to persist under selective pressure in a complex and often changing chemical environment [42]. According to Rouf [41], the inorganic elements present in bacterial samples can be classed into three groups: major, minor and trace elements. $\mathrm{Mg}, \mathrm{P}, \mathrm{K}$ and $\mathrm{S}$ are considered major elements being present in relatively high concentrations. $\mathrm{Ca}$, $\mathrm{Fe}, \mathrm{Zn}$, and, perhaps, $\mathrm{Cu}$ and $\mathrm{Mn}$ are considered minor and the rest trace elements. In biological systems, C, N, O, P and S are commonly bonded with $\mathrm{H}$. Since $60 \%$ of the cell mass is $\mathrm{H}_{2} \mathrm{O}, \mathrm{C}, \mathrm{N}$, $\mathrm{O}, \mathrm{S}$ and $\mathrm{P}$ clustered together with hydrogen to form approximately $97 \%$ of an $E$. coli cell. While Troussellier et al. [43] indicated that the elemental content can vary in taxa, Goldman et al. [44], Nakano [45], Fagerbakke et al. [46] and Vrede [47] reported that the growth condition can also affect the elemental composition. Vrede et al.
[48] showed that the macromolecule composition of a bacterial cell is affected by both growth rate and nutrient availability. In agreement with these earlier reports, there are variations in the weight (\%) of the elemental contents of the different bacteria strains used in this study while the differences between the extract-treated and untreated bacteria could be attributed to the influence of the growth conditions to which they were subjected.

Considering metabolic processes as resulting in cell growth, a lack, inhibition or breakdown of metabolic processes will result in inadequacy of the elements as structural components. Thus, in agreement with Mårdén et al. [49], Holmquist and Kjelleberg [50] and Troussellier et al. [43] who indicated that growth limitation of $\mathrm{C}, \mathrm{N}$ and $\mathrm{P}$ decreases cell volumes and ultramicrocells of bacteria, the reduction in the weight (\%) of some elemental contents of the extract-treated bacteria in comparison with those of the isolates used as control showed that the extract was able to inhibit metabolic processes essential to bacterial existence, cause a breakdown and extrusion of some of the elemental components. On the contrary, the increase in the elemental components of extract-treated bacteria as compared to those of the controls indicated that they metabolized and replicated actively in attempts to survive in the perturbed environment while the synthesized elemental contents were not completely degraded, thereafter, by the phytochemicals in the growth medium.

In addition, bacterial cell walls are made of peptidoglycan which is made from polysaccharide chains cross-linked by unusual peptides containing D-amino acids [51]. The cell membrane, built from lipids and proteins and lying just beneath the cell wall, is a biological membrane that separates the interior of all cells from the outside environment [52]. It is selectively permeable to ions and organic molecules, controls the movement of substances in and out of cells [53] and consists of the lipid layer which embedded proteins. In prokaryotic cells, proteins comprise about one-half of the dry weight [54]. In most bacterial cell membranes, the major phospholipids are neutral phosphoethanolamine $(\mathrm{PE})$, anionic phosphoglycerol (PG) and cardiolipin (CL) $[55,56]$. In E. coli cell membrane, PE, PG and CL contents are approximately 80,6 and $12 \%$ [57] 
while in $\mathrm{S}$. aureus, cell membrane $\mathrm{PE}, \mathrm{PG}$ and $\mathrm{Cl}$ contents are approximately 0,58 and $42 \%$ [58]. The lipid and protein leaked over a period of time, in this study, signified the disintegration of the cell membrane and bacterial cellular compounds, the kinetic effects of the extract and correlates with the antibacterial activity of the extract. This correlation indicated that the disruption of the cell membranes has played a vital role in the identified morphological changes in the different bacterial strains. Therefore, coupling the morphological changes, breakdown of bacterial elemental contents with the lipid and protein leakages, it could be hypothesized that the mechanism of the antibacterial activity of the extract against these isolates seems to be through inhibition of metabolic processes, cell wall and cell membrane disruption and interference with the stability of the cell membranes to cause efflux of lipid and protein in all bacteria tested. The physiological damages to the cell wall could have started within the first few minutes of treating the bacteria with the extract as indicated by the amount of leakages and the increasing intensity of the lipid and protein in the medium over the sampling periods.

In conclusion, this is the first report associating disintegration of elemental contents of bacterial isolates with the possible antibacterial effects of a medicinal plant. This study showed that morphological damages, differences in the elemental components of treated and untreated bacteria and the lipid and protein leaked were due to or could be associated with the inhibition of significant steps in peptidoglycan synthesis, binding of the antimicrobial agents to the membrane surfaces and subsequent disintegration of the cell membranes. These pharmacological effects could be linked together to give credence to the bactericidal ability of the extract and indicate its possible mechanisms of antibacterial activity against the test isolates. A further study in our research laboratory will possibly elucidate the steps inhibited in peptidoglycan synthesis by this extract.

\section{Competing interests}

The authors declare that they have no competing interests.

\section{ACKNOWLEDGMENT}

The authors wish to acknowledge the financial support of the National Research Foundation of South Africa and the University of Fort Hare, South Africa.

\section{REFERENCES}

1. Roopashree, T.S., Dang, R., Rani, S.R.H., Narendra, C. Antibacterial activity of anti psoriatic herbs: Cassia tora, Momordica charantia and Calendula officinalis. Int. J. Appl. Res. Nat. Prod., 2008; 1(3): 20-28.

2. Loziene K., Venskutonis, P.R. Sipailiene A., Labokas, J. Radical scavenging and antibacterial properties of the extracts from different Thymus pulegioides L. chemotypes. Food Chem., 2007; 103: 546-559.

3. Ahmad, I., Aqil, F. In vitro efficacy of bioactive extracts of 15 medicinal plants against ESâL producing multidrug resistant enteric bacteria, Microbiol. Res., 2007; 162: 264-275.

4. Middleton, E. Jr., Kandaswani, C., Theoharides, T.C. The effects of plant flavonoids on mammalian cells, implication for inflammation, heart disease and cancer. Pharmacol., 2000; 52: 673-751.

5. Ncube, N.S., Afolayan, A.J., Okoh, A.I. Assessment techniques of antimicrobial properties of natural compounds of plant origin: current methods and future trends. Afri. J. Biotechnol., 2008; 7(12): 1797-1806.

6. Daferera, D.J., Ziogas, B.N., Polissiou, M.G. The effectiveness of plant essential oil on growth of Botrytis cinera, Fusarium spp. and Clavibactor michinganesis sub spp. michiganesis Crop Prot., 2003; 22: 39-44.

7. Muranishi, S. Absorption enhancers. Crit. Rev. Ther. Drug Carrier Syst., 1990; 7(1): 1-33.

8. Manhong, W., Hancock, R. Interaction of the cyclic antimicrobial cationic peptide bactenecin with the outer and cytoplasmic membrane. J. Biol. Chem., 1999; 274(1): 29-35.

9. Schlemmer, U. Bioavailability of nutrients. Conceptual aspects of definition and problems of determination. Br. J. Nutr., 1995; 73: 150.

10. Li, S.X., Zheng, F.Y., Liu, X.L., Cai, W.L. Speciation analysis and assessment of bioavailability of manganese in phytomedicines by extraction with octanol and determination by flame atomic absorption spectrometry. Phytochem. Anal., 2005; 16: 405.

11. Sharma, A., Patel, V.K., Chaturvedi, A.N. Vibriocidal activity of certain medicinal plants used in Indian folklore medicine by tribals of Mahakoshal region of central India. Ind. J. 
Pharmacol., 2009; 41(3): 129-133.

12. Mohanty, S., Cock, I.E. Bioactivity of Syzygium jambos methanolic extracts: antibacterial activity and toxicity. Pharmacog. Res., 2010; 2(1): 4-9.

13. linuma, M., Tsuchiya, H., Sato, M., Yokoyama, J., Ohyama, M., Ohkawa, Y., Tanaka, T., Fujiwara, S., Fuji, T. Flavanones with potent antibacterial activity against methicillin-resistant Staphylococcus aureus. J. Pharm. Pharmacol., 1994; 46: 892-895

14. Aburjai, T., Darwish, R.M., Al-Khalil, S., Mahafza, A., Al-Abbadi, A. Screening of antibiotic resistant inhibitors from local plant materials against two different strains of Pseudomonas aeruginosa. J. Ethnopharmacol., 2001; 76: 39-44.

15. Darwish, R.M., Aburjai, T., Al-Khalil, S., Mahafza, A., Al-Abbadi, A. Screening of ntibiotic resistant inhibitors from local plant materials against two different strains of Staphylococcus aureus. J. Ethnopharmacol., 2002; 79: 359-364.

16. Young, D.A., Ferreira, D., Roux, D.G. Stereochemistry and dynamic behavior of some synthetic 'angular' profisetinidin tetraflavonoid derivatives. J Polymer Science Part A: Polymer Chem., 1986; 24: 835-849.

17. Olajuyigbe, O.O., Afolayan, A.J. In vitro antibacterial activities of crude aqueous and ethanolic extracts of Acacia mearnsii De Wild. Afr. J. Pharm. Pharmacol., 2011; 5: 1234-1240.

18. Olajuyigbe, O.O., Afolayan, A.J. Pharmacological assessment of the medicinal potential of Acacia mearnsii De Wild.: antimicrobial and toxicity activities. Int. J. Mol. Sci., 2012a; 13: 4255-4267.

19. Olajuyigbe, O.O., Afolayan, A.J. Ethnobotanical survey of medicinal plants used in the treatment of gastrointestinal disorders in the Eastern Cape Province, South Africa. J. Med. Plants Res., 2012b; 6: 3415-3424.

20. Clinical and Laboratory Standard Institute (CLSI). Performance standards for Anti-microbial susceptibility Testing Eighteenth informational supplement. M100-S18, 2008; 28(1): 46-52.

21. Sung, W.S., Jung, H.J., Lee, I.S., Kim, H.S., Lee, D.G. Antimicrobial effect of furaneol against human pathogenic bacteria and fungi. J. Microbiol. Biotechnol., 2006; 16: 349-354.

22. Figueras, M.J., Guarro, J. X-ray microanalysis of black piedra. Antonie van Leeuwenhoek 1997; 72: 275-281.

23. Frings, C.S., Dunn, R.T. A colorimetric method for determination of total serum lipids based on the sulfo-phosphovanihin reaction. Am. J. Clin. Pathol., 1970; 53: 89.

24. Van Handel, E., Day, J.F. Assay of lipids, glycogen and sugars in individual mosquitoes: correlations with wing length in field-collected Aedes vexans. J. Am. Mosquito Contrib. Ass., 1988; 4: 549-550.

25. Kaufmann, C., Brown, M.R. Regulation of carbohydrate metabolism and flight performance by a hypertrehalosaemic hormone in the mosquito Anopheles gambiae. J. Insect Physiol., 2008; 54: 367-377.

26. Bradford, M.M. A rapid and sensiutive method for the quantitation of microgram quantities of protein utilizing the principle of protein-dye binding. Anal. Biochem., 1976; 72: 248-254.

27. Ferme, D., Banjac, M., Calsamiglia, S., Busquet, M., Kamel, C., Avgustin, G. The effects of plant extracts on microbial community structure in a rumen-simulating continuous-culture system as revealed by molecular profiling. Folia Microbiol., (Praha). 2004; 49(2): 151-5.

28. Farzaneh, V., Carvalho, I.S. A review of the health benefit potentials of herbal plant infusions and their mechanisms of action. Ind. Crops Prod., 2015; 65: 247-258.

29. Gemmell, C.G., Lorian, V. Effects of low concentrations of antibiotics on bacterial ultrastructure, virulence and susceptibility to immunodefenses: Clinical significance. In: Antibiotics in Laboratory Medicine, Lorian, V. (Ed.), $4^{\text {th }}$ Edn., Wiliams and Wilkins, Baltimore, MD, pp. 1996; 397-452.

30. Giesbrecht, P., Kersten, T., Maidhof, H., Wecke, J. Staphylococcal cell wall: Morphogenesis and fatal variations in the presence of penicillin. Microbiol. Mol. Biol. Rev., 1998; 62: 1371-1414.

31. Katzung, B.G. Basic and Clinical Pharmacology, $10^{\text {th }}$ Edn., McGraw Hill Companies Inc., New Delhi, 2007.

32. Schwarz, U., Asmus, A., Frank, H. Autolytic enzymes and cell division of Escherichia coli. J. Mol. Biol., 1969; 41: 419-429.

33. Higgins, M.L., Shockman, G.D. Procaryotic cell division with respect to wall and membranes. Crit. Rev. Microbiol., 1971; 1: 29-72.

34. Satta, G., Fontana, R., Canepari, P., Botta, G. Peptidoglycan synthesis in cocci and rods of a pH-dependent, morphologically conditional mutant of Klebsiella pneumoniae. J. Bacteriol., 1979; 137: 727-734.

35. Satta, G., Canepari, P., Fontana, R. A novel hypothesis to explain regulation of the murein sacculus shape, p. 135-140. In Hakenbeck R, Holtje JV, Labischinski H. (ed.). The target of penicillin. Walter de Gruyter, Berlin, 1983.

36. Satta, G., Canepari, P., Botta, G., Fontana, F. Control of cell septation by lateral wall extension in a $\mathrm{pH}$-conditional morphology mutant of 
Klebsiella pneumoniae. J. Bacteriol., 1980; 142: 43-51.

37. Canepari, P., Botta, G., Satta, G. Inhibition of lateral wall elongation by mecillinam stimulates cell division in certain cell division conditional mutants of Escherichia coli. J. Bacteriol., 1984; 157: 130-133.

38. Satta, G., Canepari, P., Maurici, R., Marclalis, M.A. Interaction between lateral wall elongation and septum formation during cell cycle in Klebsiella pneumoniae. Ann. Microbiol., (Paris) 1985; 136A: 85-89.

39. Steinberg, R.A. Correlations between biological essentiality and atomic structure of the chemical elements. J. Agric. Res., 1938; 57: 851-858.

40. Sokoloff, V.P. Diagrams relating the periodic table to geochemistry. J. Chem. Educ., 1954; 31: 15-17.

41. Rouf, M.A. Spectrochemical analysis of inorganic elements in bacteria. J. Bacteriol., 1964; 88: 1545-1549.

42. Wackett, L.P., Dodge, A.G., Ellis, L.B.M. Minireview: Microbial Genomics and the Periodic Table. Appl. Environ. Microbiol., 2004; 70: 647-665.

43. Troussellier, M., Bouvy, M., Courties, C., Dupuy, C. Variation of carbon content among bacterial species under starvation condition. Aquatic Microb. Ecol., 1997; 13: 113-119.

44. Goldman, J.C., Caron, D.A., Denett, M.R. Regulation of gross growth efficiency and ammonium regeneration in bacteria by substrate C:N ratio. Limnol. Oceanogr., 1987; 32: 12391252.

45. Nakano, S.I. Carbon:nitrogen:phosphorus ratios and nutrient regeneration of a heterotrophic flagellate fed on bacteria with different elemental ratios. Arch. Hydrobiol., 1994; 129: 257-271.

46. Fagerbakke, K.M., Heldal, M., Norland, S. Content of carbon, nitrogen, oxygen, sulphur and phosphorus in native aquatic and cultured bacteria. Aquatic Microb. Ecol., 1996; 10: 15-27.

47. Vrede, T. Elemental composition $(\mathrm{C}: \mathrm{N}: \mathrm{P})$ and growth rates of bacteria and Rhodomonas grazed by Daphnia. J. Plankton Res., 1998; 20: 455-470.
48. Vrede, K., Heldal, M., Norland, S., Bratbak, G. Elemental composition (C, N, P) and cell volume of exponentially growing and Nutrient-Limited bacterioplankton. Appl. Environ. Microbiol., 2002; 68: 2965-2971.

49. Mårdén, P., Tunlid, A., Malmcrona-Friberg, K., Odham, G., Kjelleberg, S. Physiological and morphological changes during short term starvation of marine bacterial isolates. Arch. Microbiol., 1985; 142: 326-332.

50. Holmquist, L., Kjelleberg, S. Changes in viability, respiratory activity and morphology of the marine Vibrio sp. strain S14 during starvation of individual nutrients and subsequent recovery. FEMS Microbiol. Ecol., 1993; 12: 215-224.

51. van Heijenoort, J. Formation of the glycan chains in the synthesis of bacterial peptidoglycan. Glycobiol., 2001; 11: 25R-36R.

52. Kimball's Biology Pages, Cell Membranes http://users.rcn.com/jkimball.ma.ultranet/ BiologyPages/C/CellMembranes.html (Accessed 22/6/2012).

53. Alberts, B., Johnson, A., Lewis, J., Raff, M., Roberts, K., Walter, P. Molecular Biology of the cell. ( $4^{\text {th }}$ ed.). New York: Garland Science, 2002; ISBN 0-8153-3218-1.

54. Ingraham, J.L., Maaløe, O., Neidhardt, F.C. Growth of the bacterial cell. Sinauer Associates, Sunderland, Mass, 1983.

55. Ratledge, C., Wilkinson, S.G. Microbial Lipids, Vol. 1. Academic Press, London, 1988.

56. Lohner, K., Prenner, E.J. Differential scanning calorimetry and X-ray diffraction studies of the specificity of the interaction of antimicrobial peptides with membrane mimetic systems. Bioch. Biophys. Acta., 1999; 1462: 141-56.

57. Morein, S., Andersson, A., Rilfors, L., Lindblom, G. Wild-type Escherichia coli cells regulate the membrane lipid composition in a "window" between gel and non lamellar structures. J. Biol. Chem., 1996; 271: 6801-6809.

58. Beining, P.R., Huff, E., Prescott, B., Theodore, T.S. Characterization of the lipids of mesosomal vesicles and plasma membranes from Staphylococcus aureus. J. Bacteriol., 1975; 121: 137-143. 